\title{
Investigation on Failure Characteristics of Coal Seam Floor in Paste Filling Working Face
}

\author{
Qingliang Chang $\mathbb{D}^{1,2}$ Xingjie Yao, ${ }^{1,2}$ Chongliang Yuan, ${ }^{3}$ Qiang Leng $\mathbb{D}^{1,2}$ and Hao Wu $\mathbb{D}^{1}$ \\ ${ }^{1}$ School of Mines, China University of Mining and Technology, Xuzhou 221116, China \\ ${ }^{2}$ State Key Laboratory of Coal Resources and Safe Mining, China University of Mining and Technology, Xuzhou 221116, China \\ ${ }^{3}$ Yaojie Coal Power Group Co., Ltd., Lanzhou 730084, China
}

Correspondence should be addressed to Qiang Leng; rocksafety1114@126.com and Hao Wu; hoekwu@cumt.edu.cn

Received 21 October 2021; Accepted 9 November 2021; Published 26 November 2021

Academic Editor: Liang Xin

Copyright (C) 2021 Qingliang Chang et al. This is an open access article distributed under the Creative Commons Attribution License, which permits unrestricted use, distribution, and reproduction in any medium, provided the original work is properly cited.

\begin{abstract}
Water inrush disasters are extremely prone to occur if the coal seam floor contains a confined aquifer. To find out the failure behavior of coal seam floor of paste filling working face, a beam-based theoretical model for the floor aquifuge was built, and then, the water inrush risk was evaluated based on the thickness of floor aquifuge. Next, the floor failure characteristics of the paste filling face was numerically studied and the effects of the filling interval and long-term strength of the filling body on the floor failure depth, stress and displacement distributions, and plastic zone were explored. The results showed that the theoretical model for evaluating the safety of the floor of the paste filling face based on the empty roof distance is proved to be consistent with that of the empirical formula judged based on the assumption that the paste filling working face was regarded as a cut hole with a certain width. The filling interval has a significant effect on the stress concentration of the surrounding rock, failure depth of floor, and roof-floor convergence. The smaller the filling interval is, the smaller their values are. When the filling rate is $98 \%$, the long-term strength of the filling body is $5 \mathrm{MPa}$, and the floor failure depth is not more than $4 \mathrm{~m}$. In contrast, the strength of the filling body has no obvious influence on the floor failure depth, but it has a certain impact on the roof-floor convergence. From the perspective of reducing floor failure depth, there is no need to increase the long-term strength of backfill, but it is necessary to increase the early strength of backfill so as to reduce the width of the equivalent roadway.
\end{abstract}

\section{Introduction}

China's hydrogeological conditions are complicated, and coal mines are seriously threatened by mine water disasters. For a long time, coal mine water inrush accidents have brought huge losses to the life and property safety of the country and people [1-3]. According to relevant statistics, 1184 water disasters have occurred in coal mines of China from 2000 to 2020, with more than 5000 deaths or missing persons [4]. In particular, a quarter of the disasters occurred in the coal seam floor. With the continuous increase of mining depth, water inrush from coal seam floor becomes more and more serious $[5,6]$. This is because the coal seam floor usually contains a confined aquifer with certain water pressure, and water inrush is extremely prone to occur under the disturbance of mining activities. Therefore, it is of great significance to figure out the causes and the laws of water inrush from coal seam floor. The results can be applied to guide the safe production of coal mine [7].

Numerous scholars have made great efforts and obtained a lot of achievements in the field of water inrush from coal seam floor. It is widely accepted that coal mining above a confined aquifer involves the risk of water bursting into the mining excavation through fractured floor strata. Obviously, the hydraulic failure of the coal seam floor can result in the formation of a water inrush channel, which is an important factor causing water inrush disaster from the floor. Based on plastic theory and empirical formula, Esmailzadeh et al. [8] and Li et al. [9] analyzed and summarized the influencing factors of coal seam floor failure and divided them into two types: occurrence factors and mining design factors. After that, an "occurrence mining" multifactor 
coupling model was established, and then, FLAC software was used to simulate and verify it. Mao et al. [10] and Tian et al. [11] used the stepwise discriminant method to eliminate the indicators with insignificant discriminant effect and established Fisher discriminant analysis model. Gao et al. [12] selected coal seam thickness, coal seam permeability, mining depth, and head pressure as the main factors of floor water inrush and numerically analyzed the relation between them and water inflow. According to the theory of "in situ damage" proposed by Wang and Liu [13], the water diversion channel of the coal seam floor occurs under the combined action of horizontal extrusion, support pressure, and water pressure. Zhang and Liu [14] developed the theory of plate and shell and analyzed the failure mechanism of coal seam floor using elastic-plastic mechanics method. They divided the seam floor into a mining failure zone and a floor water-impermeable zone and regarded the waterimpermeable zone as a thin plate with clamps on all sides and uniformly distributed load and then calculated the ultimate water pressure load on the seam floor by using elastoplastic theory. In addition, "rock-water stress relationship hypothesis [15]" and "key layer theory [16-19]" all elaborated on the viewpoint that stress concentration of surrounding rock is one of the fundamental causes of coal seam floor failure. Also, fracture will initiate under high concentrated stress [20-22]. When the cracks intersect each other and extend to the workspace, a water inrush channel will be formed and failure of rock engineering will occur [23-25].

Besides, the theory of "lower three zones" put forward by $\mathrm{Li}$ [26] holds that the coaquifersal seam floor can be divided into three zones, namely, floor failure zone, complete rock protection zone, and confined water rise zone. It is noted that the floor failure zone of coal seam is caused by mining pressure. Based on the "lower three zones" analysis method, Yin et al. [27] built a conceptual model for predicting water inrush in deep mines containing multiple aquifers below the floor and deemed that there are four types of water inrush modes. With regard to the risk assessment of water inrush from the floor, a series of theoretical methods were developed to predict it, such as the PCLRA-PCLRA method [28], vulnerable index method [29], and water-inrush coefficient method [30]. Zhang and Yang [31] also presented a novel dynamic predictive method of water inrush from the coal floor based on a gated recurrent unit model, which is proven to have a high degree of reliability.

Currently, paste backfill mining technology is popularly used in coal mine due to its high safety, high recovery rate, small ground subsidence, and minor mining disturbance. In the previous work of our team, we found that the cemented paste backfill mining method is effective to control the failure depth of floor [32]. Also, Yu et al. [33] combined the strip mining method and caving zone backfill technology to recover the retained strip coal pillars above the confined aquifer and successfully prevent water inrush from the coal floor. Since the movement law of the surrounding rock of the paste backfill working face is different from that of the conventional working face and the mining space also changes [34], it is obvious the prevention and control expe- rience of water inrush from unfilled working face is no longer suitable for field application. In order to solve the threat of pressurized water to the working face and to evaluate the risk of water inrush from paste-filled working face, this paper is aimed at revealing the failure characteristics and laws of the coal seam floor in paste filling mining. In this work, based on the beam theory, a theoretical model of the paste filling floor failure was first established, and then, the floor failure law of the paste filling working face was numerically explored. This work is very useful for the control and prevention of the water inrush in paste backfill mining.

\section{Project Overview}

Daizhuang coal mine of Zibo Mining Group is located in Rencheng District of Jining City, Shandong Province, with an approved production capacity of 2.4 million ton per year. With the gradual depletion of the upper group of coal resources, the mining location will gradually transfer to the area where the floor is affected by two aquifers: thin thirteenth limestone aquifer of Carboniferous Taiyuan Formation and Ordovician limestone confined aquifer. No. 1160 district of No. 16 coal seam is the first mining area of the lower group coal, and the mining level is $-405 \sim-620 \mathrm{~m}$. It is measured that the water pressure of the thirteenth limestone aquifer reaches $4.2 \sim 6.3 \mathrm{MPa}$, and the water inflow is very large. During the process of mining using longwall caving method, the water inrush coefficient of this aquifer is $0.246 \sim 0.921 \mathrm{MPa} / \mathrm{m}$, while the water inrush coefficient of the Ordovician limestone aquifer is $0.106 \sim 0.164 \mathrm{MPa} / \mathrm{m}$. Obviously, the water inrush coefficients of the two aquifers in the floor of No. 16 coal seam in No. 1160 mining area are larger than $0.10 \mathrm{MPa} / \mathrm{m}$. Thus, it is quite difficult to mine safely using conventional mining technology, and special mining methods or special water control measures must be adopted when mining this district.

In the early production stage of the mine, the strip mining method was adopted in the No. 11605 working face of the No. 1160 district, and the designed strip width was $60 \mathrm{~m}$. Before mining, the thirteenth limestone aquifer was artificially modified into a water-resistant layer by using grouting reinforcement measures, and then, the local area of the Ordovician limestone confined aquifer was also grouted. After 146 grouting holes were constructed, the inspection found that the maximum amount of water discharged from the single borehole is $150.0 \mathrm{~m}^{3} / \mathrm{h}$, which shows that the grouting effect is not ideal. After the grouting modification of the thirteenth limestone aquifer, there are still local water-rich abnormal areas. Clearly, the thirteenth limestone aquifer still has not been completely changed into a water-proof layer. If the dewatering and depressurization method is adopted, the water pressure of the thirteenth limestone needs to be dredged, but the thickness of the aquifuge between the two aquifers in the mining area is only $23.4 \mathrm{~m}$ on average. The water release test shows that there is a vertical cross-flow relationship between the two limestone aquifers, and there is a greater possibility of hydraulic connection where the geological structure is developed, and it is difficult to guarantee the measures to drain and reduce the water 
pressure. From the above, it is concluded that there is a huge risk in the technical feasibility and economic rationality of mining the lower group of coal using the traditional stope caving method.

Practice has shown that when the aquifuge in the floor ruptures and becomes unstable, the water-inrush water channel connecting the aquifer and the working face will appear. The root cause is the disturbance of the stress field of the floor aquifuge induced by mining activities. As the deformation and failure of the floor can be dramatically suppressed by the filling body, the backfill technology becomes a very useful way for coal mining above the confined aquifers. Also, the surface subsidence can be effectively reduced after the mining space is filled, which is an effective way to mine coal under buildings and roads. Therefore, according to the successful experience of coal mining with high-water filling technology above confined aquifer in Bucun coal mine of Zibo Mining Group, Daizhuang coal mine is actively trying to apply the well-established paste filling mining technique for coal mining above limestone aquifers.

\section{Floor Aquifuge Model of Filling Working Face}

3.1. Basic Theory of Model Establishment. Based on the characteristics of paste filling, it can be seen that an interactive mechanical structure is formed between the coal roof, filling body, and coal seam floor behind the working face, and the filling body acts as a bridge in the "roof-filling bodybottom" interaction system. The filling body plays a role of bridge in the interaction relationship system of "roof-filling body-floor," It not only transmits the pressure from the roof to the floor but also supports the floor in time. Therefore, whether the strength of the filling body is sufficient to transmit the pressure from the roof will become the key to the stability of the mechanical structure of "roof-filling bodyfloor." There are two key influencing factors:

(i) Balanced hydraulic stress level: with the increasing distance from the coal wall of working face, the load of roof on filling body rises gradually. When the stress transferred from the filling body to the floor reaches the water pressure of the floor confined aquifer, i.e., the floor aquifuge is in a state of force balance. This stress level is the balanced hydraulic stress level. Thus, the strength of the filling body should be large enough to transmit this stress, and the critical strength at this time is called the water pressure resistance strength. The water pressure resistance strength of the filling body directly affects the safety of the confined water aquifuge. After that, as the distance from the coal wall of the working face continues to grow, the filling body transfers a stress greater than the balanced hydraulic stress level. The lower part of the aquifers is supported by water pressure and rock strata and is still in a state of force balance. The aquifer will remain stable without breaking and instability (ii) Original rock stress level: when the distance between the backfill and the working face increases to a certain value, the roof will apply all the weight of the overburden strata to the backfill, and the internal stress of the filling body will reach the original rock stress level first and then exceed it. The strength of the backfill should be sufficient to transfer all the weight of the overburden strata. The strength at the time is called the long-term strength and generally takes the strength of the filling body with curing age of 28 days. The final strength of the filling body directly affects the control effect of surface subsidence and the stability of the floor, as shown in Figure 1

The existing theoretical research mainly focuses on the prevention and control of floor water in traditional mining, such as the caving method. The relevant theoretical research and practice of goaf full filling method are not sufficient. Therefore, it is considered to establish a theoretical model for evaluating the safety of the floor aquifuge in the paste filling face. As the strength of the backfill behind the paste filling face is gradually increasing within a certain period of time, the supporting effect on the floor is also gradually increasing, as shown in Figure 2. When the strength of the rear filling body is increased enough to transfer the balanced hydraulic stress level, the floor aquifuge is in a state of force balance here, and the floor aquifuge between the abovementioned filling body and the coal wall of the working face can be simplified as a beam fixed on both sides. The distance between the two ends is called empty top distance (because the force of the roof on the filling body in the span of the fixed beam does not reach the level of the equilibrium water pressure, it is called empty top distance temporarily). Therefore, the beam-based model is built to study the failure process of the working face floor under the action of water pressure.

3.2. Establishment of Beam Model for Paste Backfill Face Floor. The theoretical model of floor failure in the paste filling working face is based on the following assumptions: (1) Taking the section along the advancing direction of the working face, any section can be simplified as a plane strain model. (2) In the vertical direction, the floor aquifuge is supported by both the water pressure of the lower aquifer and the rock, but the lower strata only support the aquifuge upward without downward cohesion. (3) When the strength of the filling body increases enough to transfer the equilibrium water pressure, the equilibrium point can be simplified as one end of the fixed beam. Based on the above assumptions, the theoretical model of floor failure of paste filling face is established, as plotted in Figure 3.

By means of mechanics of materials, the uniform load deflection curve of the fixed beam can be formulated as follows:

$$
w_{u}=-\frac{q x^{2}}{24 E I}\left(1-\frac{x}{L}\right)^{2}
$$


Original rock stress level

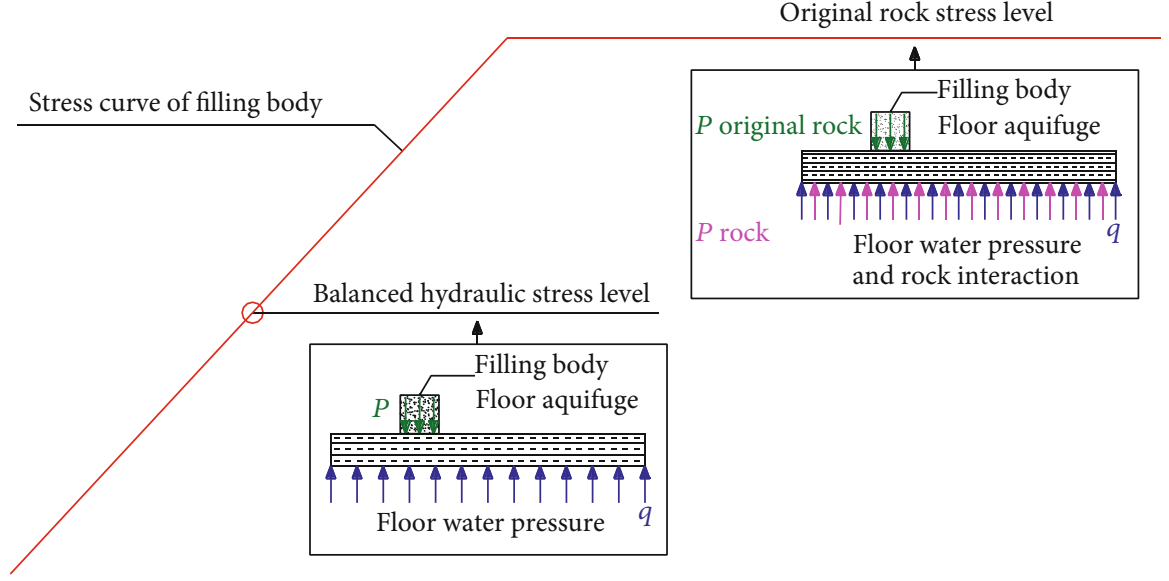

Figure 1: Variation of stress on filling body.

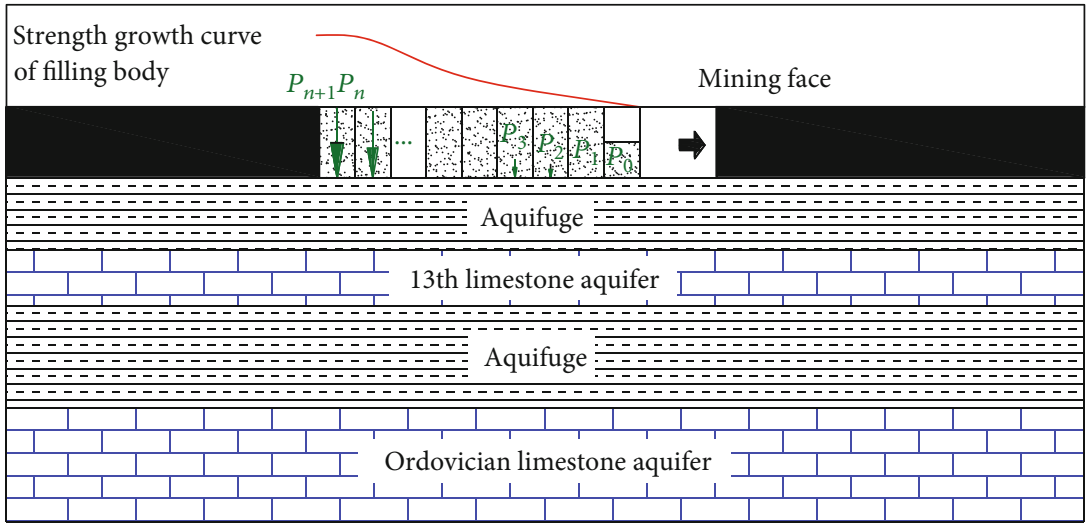

FIgURE 2: Strength change of filling body behind the working face.

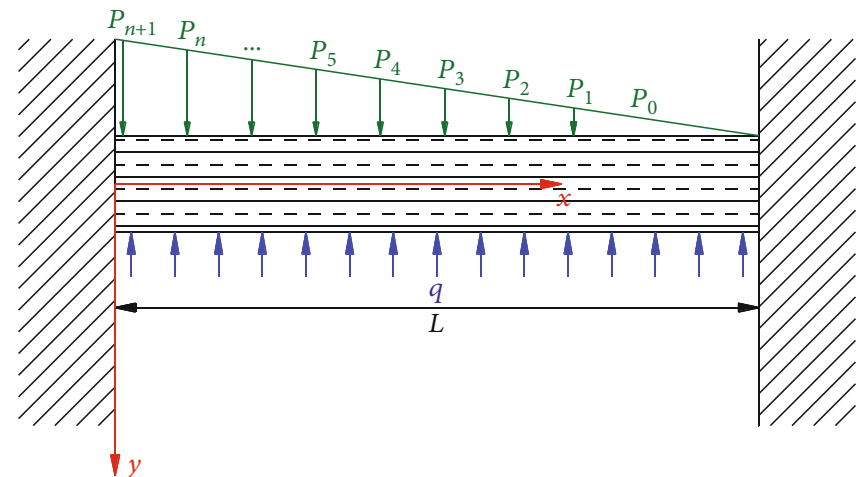

FIgURE 3: Mechanical model of the working face floor. 
The deflection curve of the fixed beam under gradual load can be written as

$$
w_{g}=\frac{q_{0} x^{2}}{120 E I L}\left(3 L^{3}-7 L^{2} x+5 L x^{2}-x^{3}\right) .
$$

After superposition operation, we can get

$$
w=\frac{q_{0} x^{2}}{120 E I L}\left(3 L^{3}-7 L^{2} x+5 L x^{2}-x^{3}\right)-\frac{q x^{2}}{24 E I}\left(x^{2}-2 L x+L^{2}\right),
$$

where $w_{u}, w_{g}$, and $w$ denote the uniform load, gradual load deflection, and superimposed deflection of fixed beam, respectively, $\mathrm{m}$. $Q$ is the resultant force of water pressure and floor weight, MPa. $q_{0}$ represents the equilibrium force of filling body on floor, MPa. $E$ means the average elastic modulus of the bottom plate, MPa. I is the moment of inertia.

When the stress of the filling body behind the working face reaches the original rock stress, $q=q_{0}$, then, the deflection equation can be given as

$$
w=-\frac{q x^{2}}{120 E I L}\left(2 L^{3}-3 L^{2} x+x^{3}\right)
$$

The bending moment is calculated as follows:

$$
M=-\frac{q L^{2}}{30}+\frac{3 q L x}{20}-\frac{q x^{3}}{6 L} .
$$

The tensile stress along the $x$-axis can be expressed as

$$
\begin{gathered}
\sigma_{x}=\frac{M y}{I_{z}} \\
\sigma_{x}=\frac{y}{I_{z}}\left(-\frac{q L^{2}}{30}+\frac{3 q L x}{20}-\frac{q x^{3}}{6 L}\right) .
\end{gathered}
$$

By means of mathematical analysis, when $x=L, y=H / 2$, the maximum stress value is

$$
\sigma_{\max }=\frac{3 q L^{2}}{10 h^{2}}=0.3 q\left(\frac{L}{h}\right)^{2}
$$

where $h$ represents the thickness of complete aquifuge, $\mathrm{m}$.

In Equation (7), it can be seen that the larger the empty top distance $L$ is, the larger the horizontal tensile stress in the lower part of the floor aquifuge is, and the easier the floor is to be damaged. When $L$ increases to a certain extent, tensile failure occurs in the floor $\left(\sigma_{\max }=\sigma_{t}\right)$. At this time, the empty top distance $L_{\max }$ of the working face is concluded as

$$
L_{\max }=h \sqrt{\frac{10 \sigma_{t}}{3 q}},
$$

where $\sigma_{t}$ is the average tensile strength of floor rock, MPa.

The empty top distance $L_{\max }$ is generally determined by the integrity of the roof and the supporting conditions. At the same time, it is determined by the conveying capacity of the filling station and the length of the working face. Whether the allowable empty top distance is appropriate or not can be evaluated by the safety factor of the empty top distance.

The definition of safety factor $k$ is introduced as

$$
k=\frac{L_{\max }}{L}, L=v t+L_{s}
$$

where $v$ is the advancing speed of working face, $\mathrm{m} / \mathrm{d}$. $t$ denotes the time for the filling body to bear the load of overburden, d. $L_{s}$ means the distance between the coal wall of working face and the nearest filling zone of goaf, $\mathrm{m}$.

$$
k=\frac{h \sqrt{10 \sigma_{t} / 3 q}}{v t+L_{\mathrm{s}}} .
$$

The above equation can be used to evaluate the safety of the floor aquifuge in the paste filling face. When the safety factor of the empty top distance $k>1.5$, it is considered safe. Through calculation, the safety factor of the empty top distance of the filling face in Daizhuang coal mine can reach $2 \sim 4$ within the range of the maximum and minimum empty top distance. This means that there will be no water inrush disasters.

3.3. Safety Verification of Floor Aquifuge in Paste Filling Face. After evaluating the floor safety according to the safety factor of empty roof distance, the paste filling working face is simplified as an open cut with width of $L$ and thus can be regarded as a driving roadway. Afterwards, the formula of safety thickness of floor aquifuge in driving roadway is extended to evaluate the safety of floor aquifuge of paste filling face. The advancing speed $\mathrm{v}$ of working face is set as $2.4 \mathrm{~m} / \mathrm{d}$, and the filling body reaches the water pressure resistance strength in two days. The correspondng equation is as follows:

$$
t=\frac{L\left(\sqrt{\gamma^{2} L^{2}+8 K_{p} p}-\gamma L\right)}{4 K_{\mathrm{p}}},
$$

where $t$ is the required thickness of safe aquifuge, $\mathrm{m} ; L$ denotes the width of roadway, $\mathrm{m} ; L=v t+L s=4.8+8.4=$ $13.2 \mathrm{~m} ; L_{\mathrm{s}}=$ branch $=6.0+2.4=8.4 \mathrm{~m} . K_{\mathrm{p}}$ means the tensile strength of floor, 1.23 MPa. $p$ is the resultant force of the water pressure of the floor limestone aquifer and the selfweight of the aquifuge, $4.4 \mathrm{MPa}$. $\gamma$ represents the unit weight of overburden, $0.025 \mathrm{MN} / \mathrm{m}^{3}$.

Substituting the above parameter values in Equation (11), we can obtain that the required thickness of the floor aquifuge is $16.8 \mathrm{~m}$ even if the safety factor takes the minimum value. According to the drilling data of the area, the minimum 


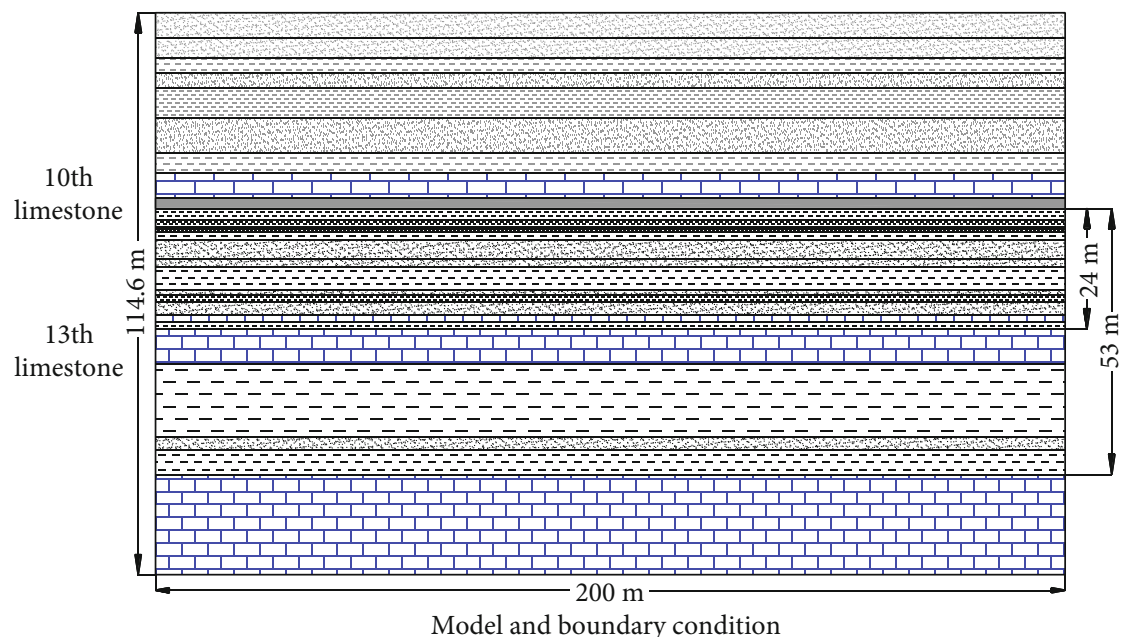

FIGURE 4: Numerical simulation model and boundary condition.

thickness of the floor aquifuge is $18.5 \mathrm{~m}$, which meets the requirements of the relevant regulations [35]. As a result, it is believed that the application of paste filling mining technology on No. 16 coal seam can prevent water inrush from the thirteenth limestone aquifer, which is safe and feasible.

\section{Numerical Simulation of Floor Failure Law in Paste Filling Face}

4.1. Construction of Numerical Model. As an effective and low-cost way to characterize the failure and deformation of rock engineering, the numerical method is widely used in rock engineering, especially in rock fracture mechanics [36-38]. In this research, Flac software was selected for numerical modelling. With regard to its principle and purpose, please refer to references $[39,40]$. In order to meet the accuracy of the results and close to the field conditions, based on the floor hydrological data and borehole (No. 152, L10-2 and L10-4) data of No. 11607 working face, the thinnest part of the floor aquifuge was selected as the simulation object, that is, $24 \mathrm{~m}$ according to the data of No. 11607-2 borehole).

The specific model simplification and parameter setting are as follows: (1) The inclined length of the working face is $120 \mathrm{~m}$. A vertical section is taken along the advancing direction of the working face and the middle of the vertical working face. Each rock layer conforms to the assumption of the plane strain model, so it can be simplified as a plane strain problem. (2) The thickness of the simulated coal seam is $2 \mathrm{~m}$, and the coal seam floor is $24 \mathrm{~m}$ from the upper boundary of the 13th limestone and $53 \mathrm{~m}$ from the upper boundary of the Ordovician limestone. The roof of the coal seam is $39.6 \mathrm{~m}$ away from the upper boundary of the model, and the upper and lower boundaries of the model are enough to cover the "upper three zones, lower three zones" of the paste filling working face and the main aquifers that have an impact on the coal seam mining. (3) In order to reduce the influence of boundary effect, the width of the model is set as $200 \mathrm{~m}$, and the advancing distance of the
TABLE 1: Supporting parameters of hydraulic support for filling No. 16 coal in Daizhuang mine.

\begin{tabular}{lcc}
\hline Type & Units & Value \\
\hline Top beam length & $\mathrm{mm}$ & 5785 \\
Center distance & $\mathrm{mm}$ & 1500 \\
Theoretical initial support force of column & $\mathrm{KN} /$ column & 1300 \\
Theoretical working resistance of support & $\mathrm{KN}$ & 6200 \\
\hline
\end{tabular}

working face is $100 \mathrm{~m}$. At this time, the working face is $100 \mathrm{~m}$ away from the boundary on both sides of the model, and the influence range of the abutment pressure of the working face is generally not more than $100 \mathrm{~m}$. Therefore, the influence of the boundary effect can be eliminated. The model is illustrated in Figure 4.

\subsection{Boundary Conditions and Determination of Mechanical Parameters of Surrounding Rock}

\section{(1) Overburden load}

The average buried depth of No. 11607 working face is about $541.6 \mathrm{~m}$. The distance from No. 16 coal seam to the upper boundary in the model is $39.6 \mathrm{~m}$, and the volume density of rock strata from the upper boundary to surface is $0.025 \mathrm{MN} / \mathrm{m}^{3}$. The upper boundary load of the model is calculated according to the hydrostatic pressure:

$$
P=H \gamma
$$

where $P$ is upper boundary load of the model, MPa. $H$ means the vertical depth from the upper boundary of the model to the surface, $541.6-39.6=502 \mathrm{~m}$. $\gamma$ represents the unit weight of overburden, $0.025 \mathrm{MN} / \mathrm{m}^{3}$.

Based on this calculation, the action of rock above the upper boundary of the model can be simplified as a uniform stress of $12.55 \mathrm{MPa}$. 
TABLE 2: Physical and mechanical parameters of rock strata for numerical modelling.

\begin{tabular}{|c|c|c|c|c|c|c|c|}
\hline Number & Rock type & $\begin{array}{l}\text { Bulk modulus } \\
\qquad(\mathrm{GPa})\end{array}$ & $\begin{array}{l}\text { Shear modulus } \\
(\mathrm{GPa})\end{array}$ & $\begin{array}{c}\text { Internal friction } \\
\text { angle }\left({ }^{\circ}\right)\end{array}$ & $\begin{array}{l}\text { Cohesion } \\
(\mathrm{MPa})\end{array}$ & $\begin{array}{c}\text { Tensile strength } \\
(\mathrm{MPa})\end{array}$ & $\begin{array}{c}\text { Density (kg/ } \\
\left.\mathrm{m}^{3}\right)\end{array}$ \\
\hline 27 & Fine sandstone & 1.20 & 0.87 & 38 & 7.41 & 0.64 & 2740 \\
\hline 26 & Siltstone & 1.20 & 0.87 & 38 & 7.41 & 0.64 & 2740 \\
\hline 25 & Mudstone & 0.35 & 0.21 & 35 & 4.53 & 0.20 & 2600 \\
\hline 24 & Fine sandstone & 1.20 & 0.87 & 38 & 7.41 & 0.64 & 2740 \\
\hline 23 & Mudstone & 0.35 & 0.21 & 35 & 4.53 & 0.20 & 2600 \\
\hline 22 & Siltstone & 1.31 & 0.94 & 38 & 7.41 & 0.79 & 2740 \\
\hline 21 & Mudstone & 0.39 & 0.24 & 35 & 4.53 & 0.24 & 2600 \\
\hline 20 & 10 limestone & 2.00 & 1.56 & 40 & 8.69 & 0.84 & 2740 \\
\hline 19 & 16 coal seam & 0.07 & 0.03 & 37 & 2.34 & 0.09 & 1600 \\
\hline 18 & Mudstone & 0.30 & 0.18 & 35 & 4.53 & 0.14 & 2600 \\
\hline 17 & Fine sandstone & 1.20 & 0.87 & 38 & 7.41 & 0.64 & 2680 \\
\hline 16 & Mudstone & 0.35 & 0.21 & 35 & 4.53 & 0.20 & 2600 \\
\hline 15 & Coal seam & 0.09 & 0.04 & 37 & 2.34 & 0.12 & 1600 \\
\hline 14 & Mudstone & 0.35 & 0.21 & 35 & 4.53 & 0.20 & 2600 \\
\hline 13 & Siltstone & 1.20 & 0.87 & 38 & 7.41 & 0.64 & 2740 \\
\hline 12 & Fine sandstone & 1.20 & 0.87 & 38 & 7.41 & 0.64 & 2740 \\
\hline 11 & Mudstone & 0.35 & 0.21 & 35 & 4.53 & 0.20 & 2600 \\
\hline 10 & Siltstone & 1.20 & 0.87 & 38 & 7.41 & 0.64 & 2740 \\
\hline 9 & Mudstone & 0.35 & 0.21 & 35 & 4.53 & 0.20 & 2600 \\
\hline 8 & Siltstone & 1.20 & 0.87 & 38 & 7.41 & 0.64 & 2740 \\
\hline 7 & 12 limestone & 1.68 & 1.31 & 40 & 8.69 & 0.57 & 2780 \\
\hline 6 & Mudstone & 0.35 & 0.21 & 35 & 4.53 & 0.20 & 2600 \\
\hline 5 & 13 limestone & 1.68 & 1.31 & 40 & 8.69 & 0.57 & 2780 \\
\hline 4 & $\begin{array}{l}\text { Variegated } \\
\text { mudstone }\end{array}$ & 0.37 & 0.21 & 35 & 4.48 & 0.16 & 2600 \\
\hline 3 & Sandstone & 1.20 & 0.87 & 38 & 7.41 & 0.64 & 2740 \\
\hline 2 & Mudstone & 0.35 & 0.21 & 35 & 4.53 & 0.20 & 2600 \\
\hline 1 & $\begin{array}{l}\text { Ordovician } \\
\text { limestone }\end{array}$ & 1.68 & 1.31 & 40 & 8.69 & 0.57 & 2780 \\
\hline
\end{tabular}

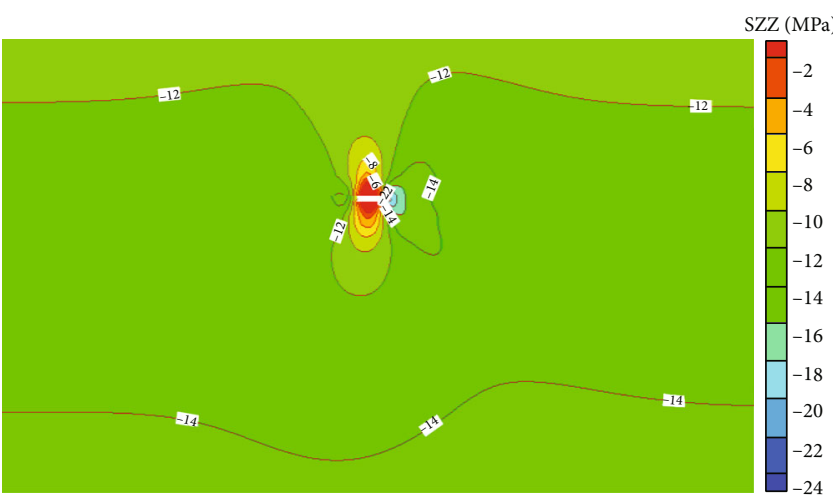

(a) Filling interval $1.2 \mathrm{~m}$

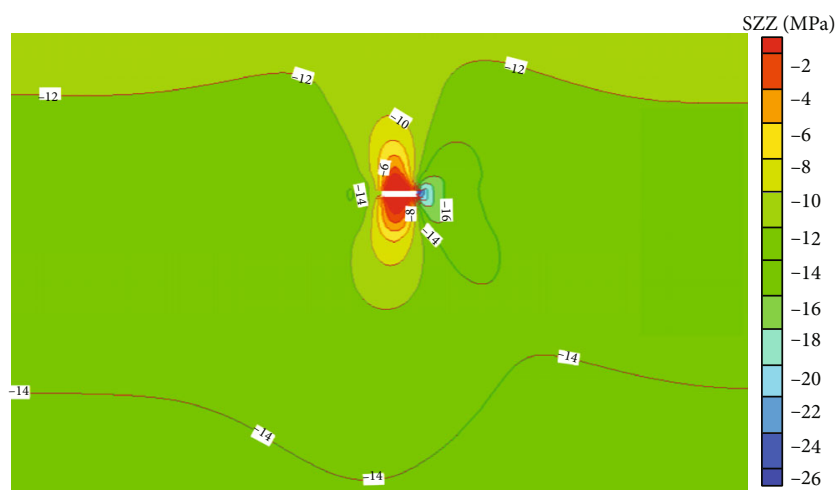

(b) Filling interval $3.6 \mathrm{~m}$

FIGURE 5: Vertical stress distribution around the working face with different filling intervals. 


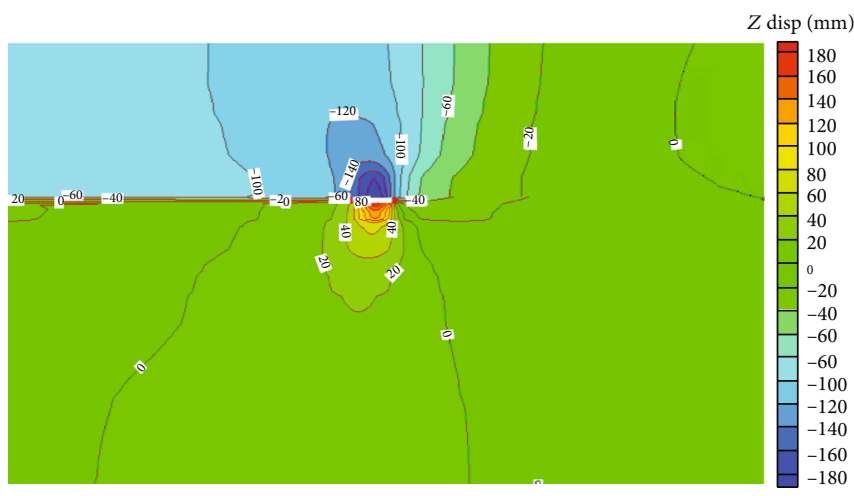

(a) Filling interval $1.2 \mathrm{~m}$

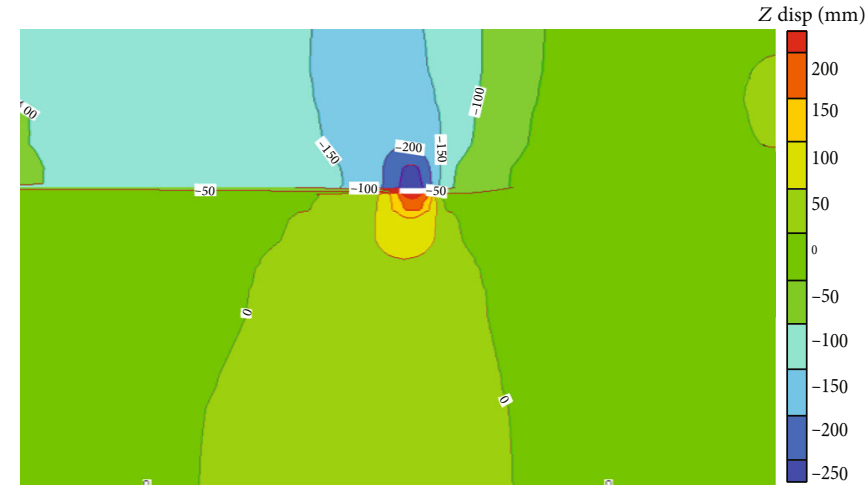

(b) Filling interval $3.6 \mathrm{~m}$

FIgURE 6: Vertical displacement distribution around the working face with different filling intervals.

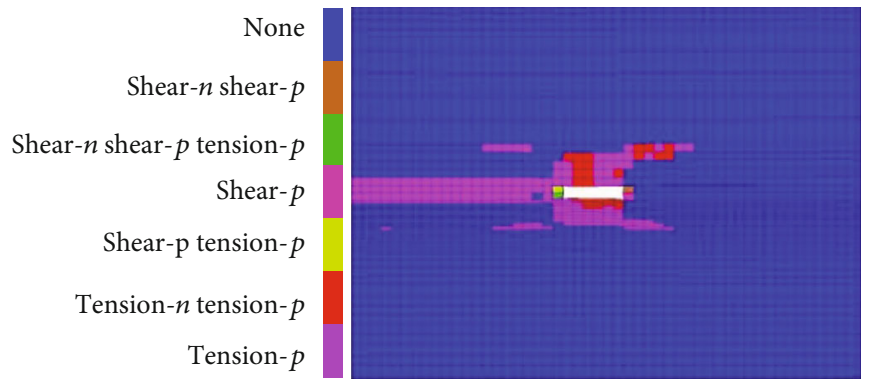

(a) Filling interval $1.2 \mathrm{~m}$

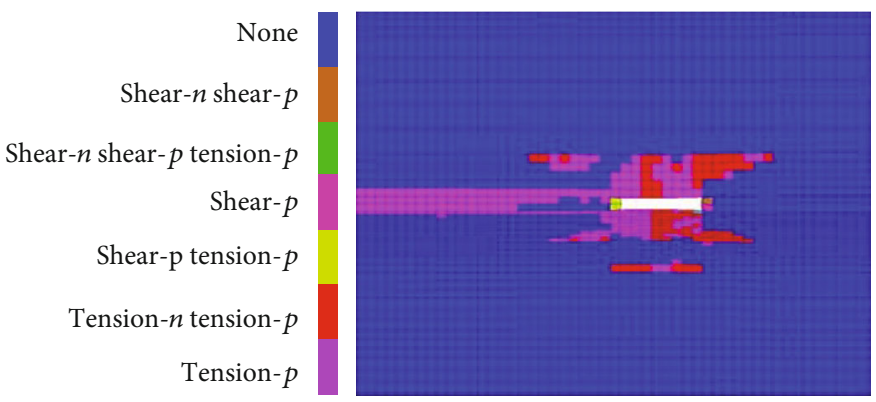

(b) Filling interval $3.6 \mathrm{~m}$

FIgURE 7: Plastic zone distribution around the working face with different filling intervals.

(2) Hydraulic action

According to the data of 9 hydrological boreholes in No. 11607 working face, the maximum water pressure of thirteenth limestone aquifer is $4.4 \mathrm{MPa}$, while that of the Ordovician limestone is about $4.7 \mathrm{MPa}$.

(3) Supporting function of hydraulic support

The supporting parameters of No. 16 coal seam filling support in Daizhuang coal mine are shown in Table 1.

According to the observation of mine pressure in the working face, the actual working resistance of some supports is about $80 \%$ of the initial support force. Therefore, for the sake of safety, $80 \%$ of the theoretical support strength of the support is taken when calculating the support strength. Considering that there is a certain distance between the front section of the top beam and the coal wall, the length of the top beam is $6 \mathrm{~m}$ and $P$ is calculated as $(0.8 \times 6.2) /(1.5 \times 6)$ $\approx 0.5 \mathrm{MPa}$.

Based on the above field data, the model boundary conditions are set as follows: (1) The lower boundary is fixed. (2) The $x$ direction displacement of the left and right boundaries is fixed. (3) The displacement of front and back boundaries is fixed in $y$ direction. (4) A uniform downward stress of $12.55 \mathrm{MPa}$ is applied to the upper boundary. (5) The upper boundary of Ordovician limestone is exerted an upward pressure of $4.7 \mathrm{MPa}$. (6) The upward pressure of $4.4 \mathrm{MPa}$ is applied to the upper boundary of the thirteenth limestone. (7) A supporting force of $0.5 \mathrm{MPa}$ is applied to the roof and floor within $6 \mathrm{~m}$ behind the coal wall of the working face to simulate the supporting effect of the support, and a filling interval is left behind the support without any support to simulate the area to be filled. 


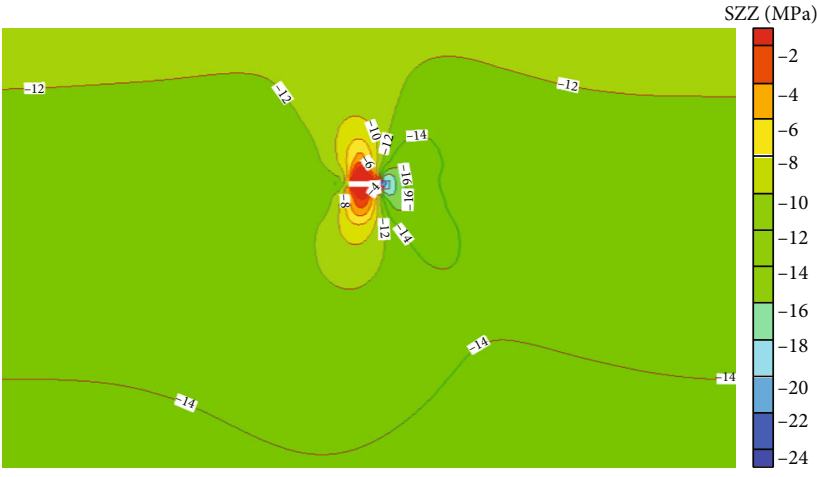

(a) Filling body strength $3 \mathrm{MPa}$

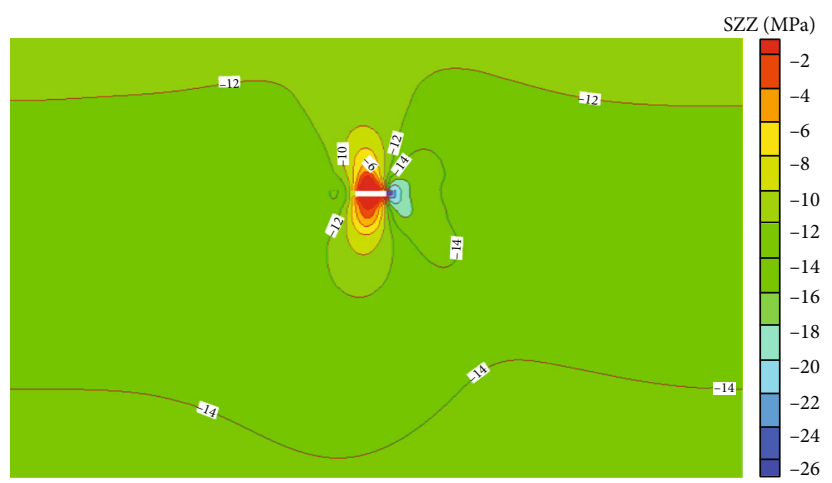

(c) Filling body strength $5 \mathrm{MPa}$

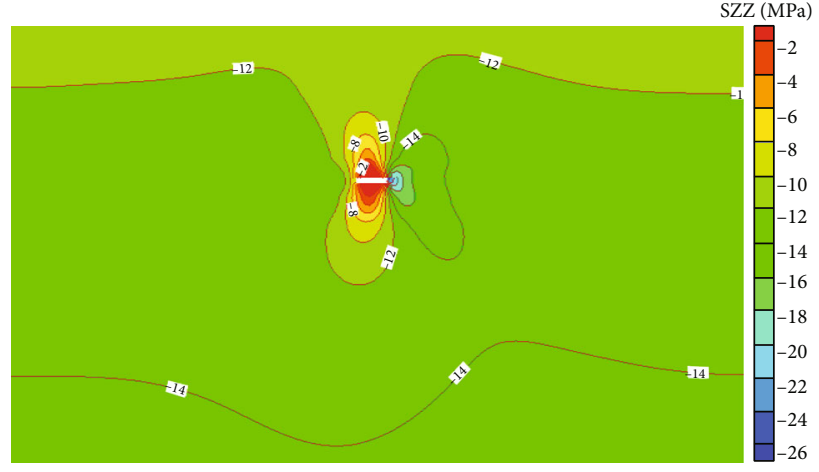

(b) Filling body strength $4 \mathrm{MPa}$

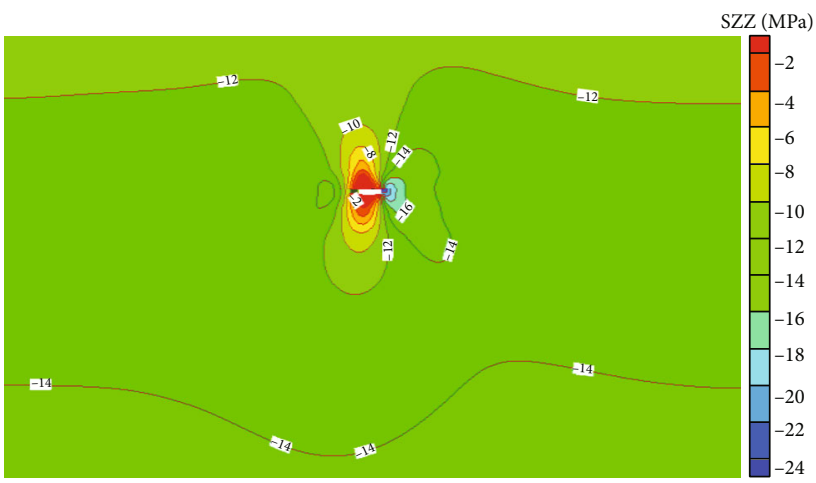

(d) Filling body strength $7 \mathrm{MPa}$

FIGURE 8: Vertical stress distribution around the working face with different backfill strengths.

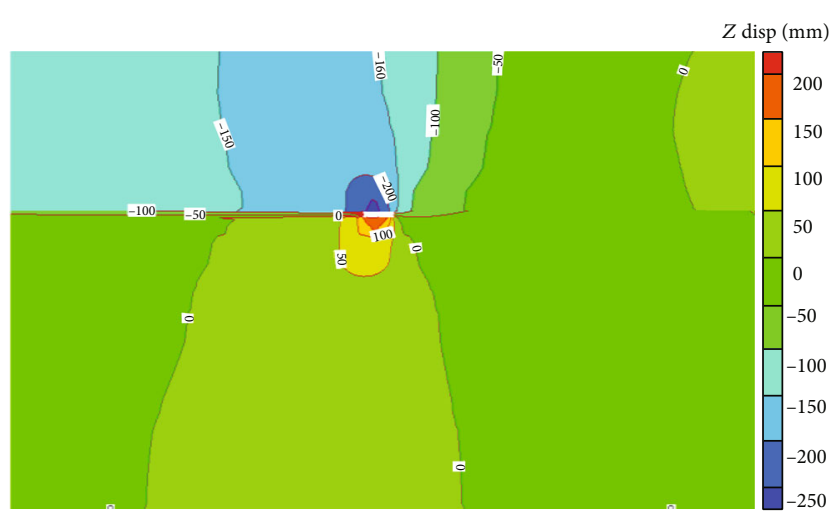

(a) Filling body strength $3 \mathrm{MPa}$

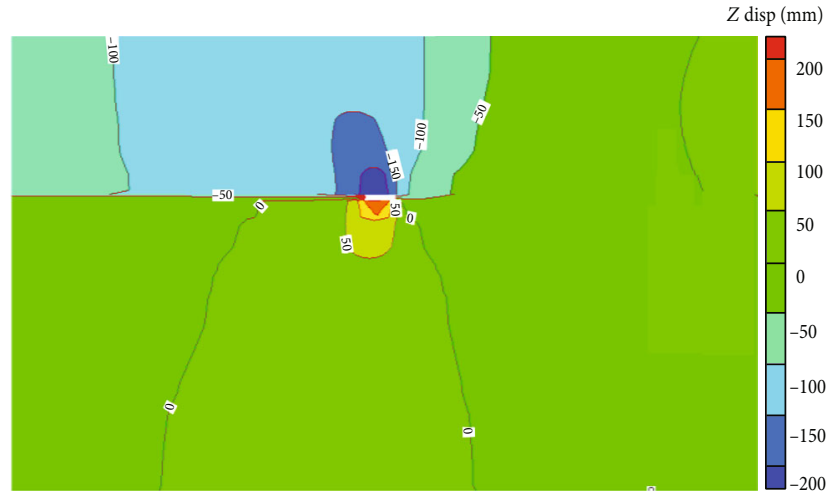

(c) Filling body strength $5 \mathrm{MPa}$

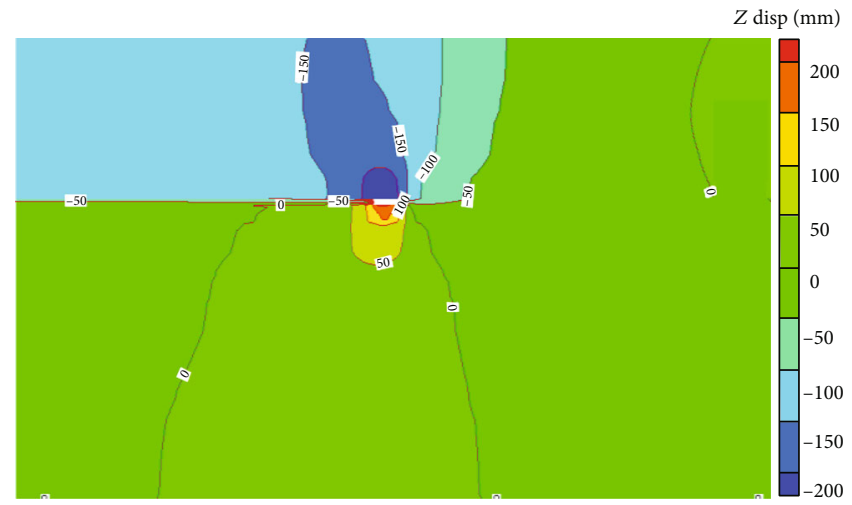

(b) Filling body strength $4 \mathrm{MPa}$

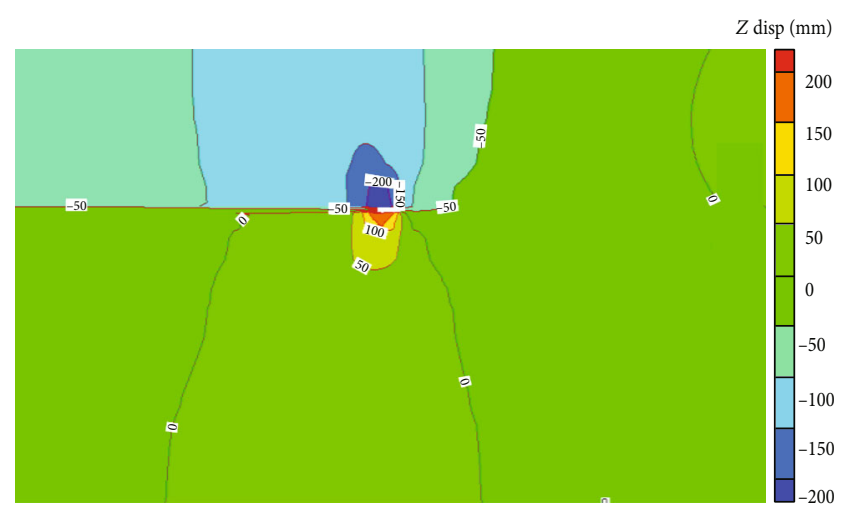

(d) Filling body strength $7 \mathrm{MPa}$

FIGURE 9: Vertical displacement distribution around the working face with different backfill strengths. 


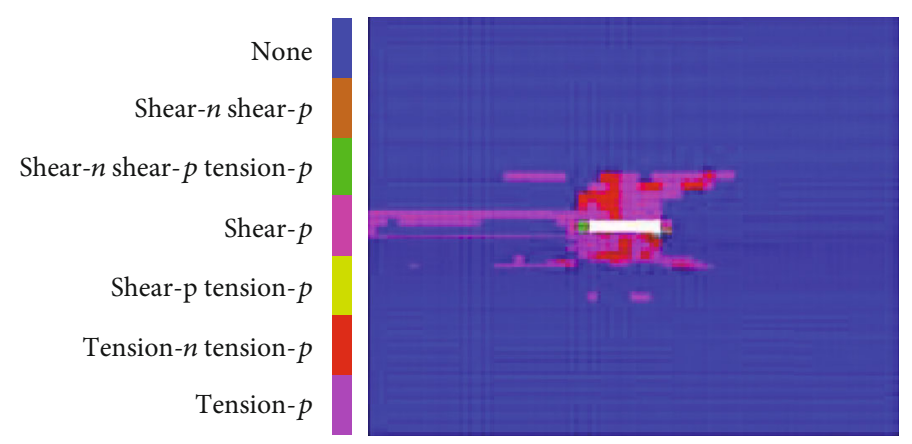

(a) Filling body strength $3 \mathrm{MPa}$

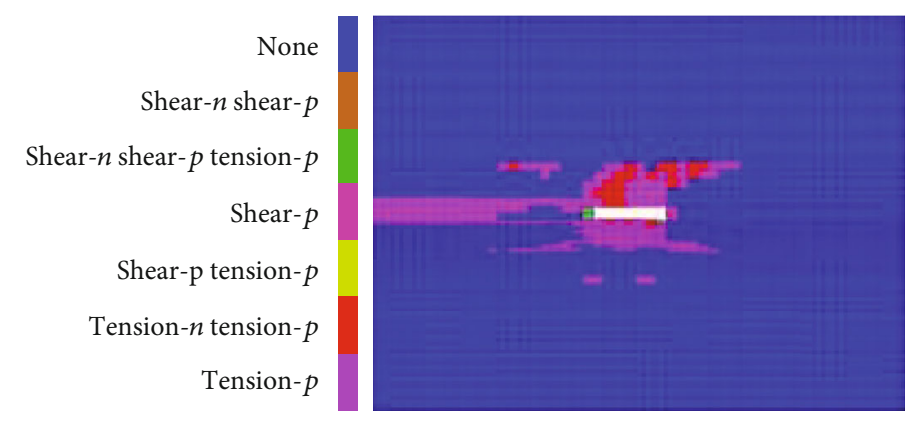

(b) Filling body strength $4 \mathrm{MPa}$

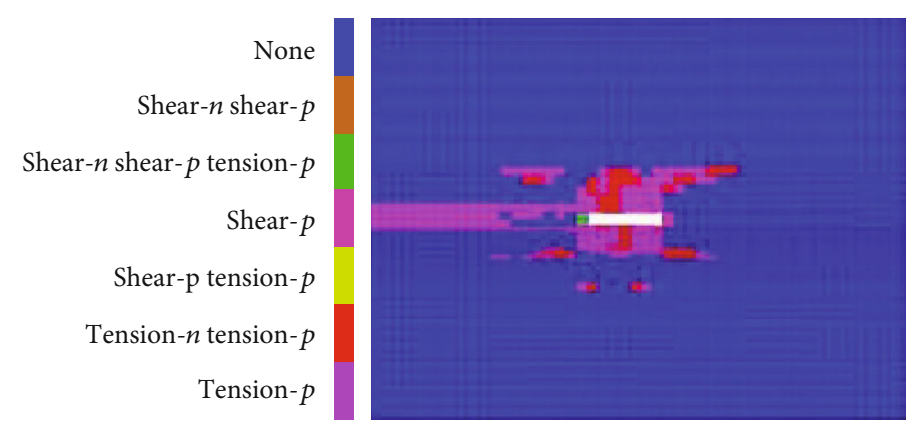

(c) Filling body strength $5 \mathrm{MPa}$

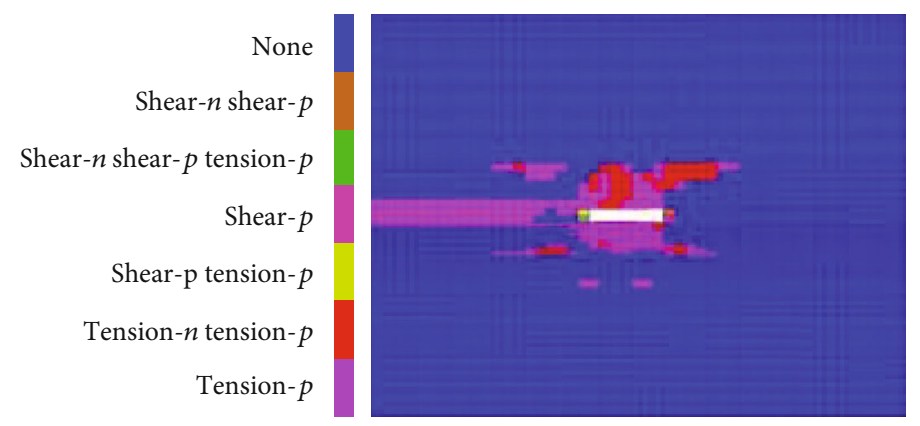

(d) Filling body strength $7 \mathrm{MPa}$

FIGURE 10: Plastic zone range around the working face with different backfill strengths.

According to the floor geological data of the deep lower coal group in Daizhuang coal mine and the test results of the physical and mechanical properties of the core as well as the classification results of the engineering rock mass quality using RMR method, the mechanical and physical parameters of the rock strata used for numerical modelling are reduced based on the laboratory rock test results, as shown in Table 2.
4.3. Simulation Scheme. The numerical calculation mainly studies the influence of filling interval and strength $(28 \mathrm{~d}$ curing time) of filling body on the failure depth of floor. The detailed scheme is described as follows:

(1) Setting the filling rate is $98 \%$ and the strength of filling body is $5 \mathrm{MPa}$, the effects of different filling intervals $(1.2 \mathrm{~m}, 3.6 \mathrm{~m})$ on the stress concentration of 
floor, deformation of surrounding rock and distribution of plastic zone are analyzed, and the influence of filling interval on the failure depth of floor is studied

(2) Setting the filling rate of $98 \%$ and the filling interval of $2.4 \mathrm{~m} / \mathrm{d}$, the stress concentration, surrounding rock deformation and plastic zone distribution of the floor under different filling body strengths $(28 \mathrm{~d}$ strength of $3 \mathrm{MPa}, 4 \mathrm{MPa}, 5 \mathrm{MPa}$, and $7 \mathrm{MPa}$ ) are analyzed, and the influence of filling body strength on the failure depth of the floor is studied

\subsection{Analysis of Numerical Simulation Results}

(1) Analysis of the influence of filling interval on the stress and failure of the surrounding rock in stope. Setting the working face forward $100 \mathrm{~m}$ and the $28 \mathrm{~d}$ strength of filling body is $5 \mathrm{MPa}$; the stress concentration of floor, deformation of surrounding rock, and distribution of plastic zone under different filling intervals $(1.2 \mathrm{~m}$ and $3.6 \mathrm{~m})$ are analyzed. The simulation results are presented in Figures 5-7 (the middle of the working face is cut along the advancing direction of the working face)

As can be seen from Figures 5-7, when the filling interval increases from $1.2 \mathrm{~m}$ to $3.6 \mathrm{~m}$, the maximum vertical stress of surrounding rock increases from $24 \mathrm{MPa}$ to $26 \mathrm{MPa}$. Therefore, the increase of filling interval will increase the peak stress of the surrounding rock. In contrast, the maximum roof subsidence grows from $180 \mathrm{~mm}$ to $250 \mathrm{~mm}$, and the floor heave rises from $180 \mathrm{~mm}$ to $200 \mathrm{~mm}$. When the filling interval is $1.2 \mathrm{~m}$, the floor failure depth is about $3.6 \mathrm{~m}$, and the failure depth runs through the mudstone and fine-grained sandstone below the coal floor. When the filling interval is $3.6 \mathrm{~m}$, the penetration depth of the floor failure zone is still $3.6 \mathrm{~m}$, and the plastic zone of siltstone at $6.3 \mathrm{~m}$ from the upper boundary of the coal seam floor continues to expand. The development of the plastic zone of the floor presents the trend of delamination failure. The reason for the phenomenon is that the large the filling interval, the large the stope space is. As a result, the failure and deformation is more serious and the concentrated stress increases sharply.

Generally speaking, the distribution of stress field, displacement field, and plastic zone of paste filling face is similar to those of a roadway. The difference is that the peak stress and plastic zone of coal wall side are larger than that of filling body side, and the vertical displacement of filling body side is larger than that of the coal wall side.

(2) Analysis of influence of backfill strength on stress and failure of surrounding rock

Setting the advancing distance of the working face to $100 \mathrm{~m}$, the filling rate is $98 \%$, and the filling interval is $2.4 \mathrm{~m} / \mathrm{d}$. Under such a case, the floor stress concentration, surrounding rock deformation, and plastic zone distribution under different filling body strengths ( $3 \mathrm{MPa}, 4 \mathrm{MPa}, 5 \mathrm{MPa}$, and $7 \mathrm{MPa}$ ) are analyzed. The simulation results are shown in Figures 8-10 (the section is made along the advancing direction of the working face in the middle of the working face).

As can be seen from Figures $8-10$, when the $28 \mathrm{~d}$ strength of backfill increases from $3 \mathrm{MPa}$ to $7 \mathrm{MPa}$, the maximum vertical stress of surrounding rock decreases from $26 \mathrm{MPa}$ to $24 \mathrm{MPa}$, and the range of stress concentration decreases gradually. With the increase of $28 \mathrm{~d}$ strength of backfill from $3 \mathrm{MPa}$ to $7 \mathrm{MPa}$, the maximum roof subsidence decreases from $250 \mathrm{~mm}$ to $200 \mathrm{~mm}$, and the floor heave has no obvious change. In the process of increasing the $28 \mathrm{~d}$ strength of the filling body, the depth of the plastic zone of the floor has not changed much, and only the range of the plastic zone has a slight change. From the above, it can be concluded that the deformation and failure are remarkably suppressed by the increasing strength of filling body. This is because the filling body has a certain bearing capacity and could support the roof and floor. Also, the larger the strength of filling body, and stronger its bearing capacity is.

\section{Conclusions}

In this work, the floor failure characteristics of paste backfill working face above limestone aquifers were systematically investigated. First, the water inrush risk from the floor was assessed based on a built beam model. Next, the failure response of the paste backfill working face was numerically studied. Results of this study could provide some valuable insight into the mechanism of water inrush from coal seam floor. The main conclusions can be drawn as follows:

(1) The theoretical thickness of the safety floor aquifuge required by the Daizhuang coal mine is $16.8 \mathrm{~m}$. According to regional drilling data, the minimum thickness of the aquifuge is $18.5 \mathrm{~m}$, indicating that the water inrush risk of the paste backfill working face is very small

(2) The stress concentration of surrounding rock, failure depth of floor, and convergence of roof and floor are significantly affected by the filling interval. The smaller the filling interval, the smaller the stress concentration range and peak value of the surrounding rock, the convergence between the roof and floor, and the plastic zone of the floor

(3) The $28 \mathrm{~d}$ strength of filling body has no obvious effect on the failure depth of floor but has a certain influence on the convergence of roof and floor and the peak stress of surrounding rock. Therefore, the final strength of filling body should be determined for the purpose of surface protection and long-term stability of filling zone. The purpose of determining the early strength of backfill is to reduce the equivalent roadway width and the floor failure depth

\section{Data Availability}

The data used to support the findings of this study are included within the article. 


\section{Conflicts of Interest}

The authors declared no potential conflicts of interest with respect to the research, authorship, and/or publication of this article.

\section{Acknowledgments}

This work was supported by the National Natural Science Foundation of China (52174130) and the Natural Science Foundation of Jiangsu Province (BK20210515) as well the Fundamental Research Funds for the Central Universities (2021QN1010).

\section{References}

[1] H. T. Yu, S. Y. Zhu, and Y. Chen, "Comparative analysis of water inrush from the deep coal floor by mining above the confined aquifer," Journal of Mining Science, vol. 55, no. 3, pp. 407-413, 2019.

[2] K. Polak, K. Różkowski, and P. Czaja, "Causes and effects of uncontrolled water inrush into a decommissioned mine shaft," Mine Water and the Environment, vol. 35, no. 2, pp. 128-135, 2016.

[3] Y. Zhao, G. Y. Zhao, J. Zhou, J. Ma, and X. Cai, "Failure mechanism analysis of rock in particle discrete element method simulation based on moment tensors," Computers and Geotechnics, vol. 136, Article ID 104215, 2021.

[4] S. N. Dong, L. W. Zheng, S. L. Tang, and P. Shi, "A scientometric analysis of trends in coal mine water inrush prevention and control for the period 2000-2019," Mine Water and the Environment, vol. 39, no. 1, pp. 3-12, 2020.

[5] B. Haimson, W. Lin, H. Oku, J. H. Hung, and S. R. Song, "Integrating borehole-breakout dimensions, strength criteria, and leak-off test results, to constrain the state of stress across the Chelungpu Fault, Taiwan," Tectonophysics, vol. 482, no. 1-4, pp. 65-72, 2010.

[6] K. Ma, X. Y. Sun, C. A. Tang, F. Z. Yuan, S. J. Wang, and T. Chen, "Floor water inrush analysis based on mechanical failure characters and microseismic monitoring," Tunnelling and Underground Space Technology, vol. 108, article 103698, 20211.

[7] J. C. Zhang, "Investigations of water inrushes from aquifers under coal seams," International Journal of Rock Mechanics and Mining Sciences, vol. 42, no. 3, pp. 350-360, 2005.

[8] A. Esmailzadeh, R. Mikaeil, E. Shafei, and G. Sadegheslam, "Prediction of rock mass rating using TSP method and statistical analysis in Semnan Rooziyeh spring conveyance tunnel," Tunnelling and Underground Space Technology, vol. 79, pp. 224-230, 2018.

[9] A. Li, B. N. Ji, Q. Ma et al., "Design of longwall coal pillar for the prevention of water inrush from the seam floor with through fault," Geofluids, vol. 2021, Article ID 5536235, 14 pages, 2021.

[10] D. Q. Mao, Z. B. Liu, W. K. Wang et al., "An application of hydraulic tomography to a deep coal mine: combining traditional pumping tests with water inrush incidents," Journal of Hydrology, vol. 567, pp. 1-11, 2018.

[11] Y. Tian, W. Z. Chen, H. M. Tian, X. J. Tan, Z. Li, and J. Lei, "Parameter design of yielding layers for squeezing tunnels,"
Tunnelling and Underground Space Technology, vol. 108, article 103694, 2021.

[12] R. Gao, H. Yan, F. Ju, X. Mei, and X. Wang, "Influential factors and control of water inrush in a coal seam as the main aquifer," International Journal of Mining Science and Technology, vol. 28, no. 2, pp. 187-193, 2018.

[13] Z. Y. Wang and H. Q. Liu, Coal Mining on Confined Water, China Coal Industry Publishing House, Beijing, 1993.

[14] J. C. Zhang and T. Q. Liu, "On depth of fissured zone in seam floor resulted from coal extraction and its distribution characteristics," Mei T'an Hsueh Pao (Journal of China Coal Society);(China), vol. 15, pp. 46-55, 1990.

[15] J. Y. Song and C. X. Wang, "On the statics effect of confined water in rock fracture," in Collected Works of Xi'an Branch of China Coal Research Institute, vol. 5, pp. 56-62, Shaanxi Science and Technology Press, Xi'an, 1991.

[16] M. G. Qian, X. X. Miao, and L. J. Li, "Mechanical behaviour of main floor for water inrush in longwall mining," Journal of China University and Technology, vol. 5, no. 1, pp. 9-16, 1995.

[17] Q. L. Chang, W. J. Tang, Y. Xu, and H. Zhou, "Research on the width of filling body in gob-side entry retaining with highwater materials," International Journal of Mining Science and Technology, vol. 28, no. 3, pp. 519-524, 2018.

[18] H. Shimada, A. Hamanaka, T. Sasaoka, and K. Matsui, "Behaviour of grouting material used for floor reinforcement in underground mines," International Journal of Mining Reclamation and Environment, vol. 28, no. 2, pp. 133-148, 2014.

[19] A. K. Gupta and B. Paul, "A review on utilisation of coal mine overburden dump waste as underground mine filling material: a sustainable approach of mining," International Journal of Mining and Mineral Engineering, vol. 6, no. 2, pp. 172-186, 2015.

[20] P. Hou, X. Liang, Y. Zhang, J. He, F. Gao, and J. Liu, “3D multiscale reconstruction of fractured shale and influence of fracture morphology on shale gas flow," Natural Resources Research, vol. 30, no. 3, pp. 2463-2481, 2021.

[21] P. Hou, X. Liang, F. Gao, J. Dong, J. He, and Y. Xue, "Quantitative visualization and characteristics of gas flow in $3 \mathrm{~d}$ porefracture system of tight rock based on lattice Boltzmann simulation," Journal of Natural Gas Science and Engineering, vol. 89, no. 4, article 103867, 2021.

[22] H. Wu, D. Ma, A. J. S. Spearing, and G. Zhao, "Fracture phenomena and mechanisms of brittle rock with different numbers of openings under uniaxial loading," Geomechanics and Engineering, vol. 25, no. 6, pp. 481-493, 2021.

[23] X. Liang, P. Hou, Y. Xue, X. J. Yang, F. Gao, and J. Liu, “A fractal perspective on fracture initiation and propagation of reservoir rocks under water and nitrogen fracturing," FractalsComplex Geometry Patterns and Scaling in Nature and Society, vol. 29, no. 7, article 2150189, 2021.

[24] S. Luo and F. Q. Gong, "Linear energy storage and dissipation laws during rock fracture under three- point flexural loading," Engineering Fracture Mechanics, vol. 234, article 107102, 2020.

[25] D. Z. Kong, S. J. Pu, Z. H. Cheng, G. Wu, and Y. Liu, "Coordinated deformation mechanism of the top coal and filling body of gob-side entry retaining in a fully mechanized caving face," International Journal of Geomechanics, vol. 21, no. 4, article 04021030, 2021.

[26] B. Y. Li, “"Down three zones" in the prediction of the water inrush from coalbed floor aquifer theory, development and application," Journal of Shandong Institute of Mining and Technology (Natural Science), vol. 18, no. 4, pp. 11-18, 1999. 
[27] L. Yin, K. Ma, J. Chen, Y. Xue, Z. Wang, and B. Cui, "Mechanical model on water inrush assessment related to deep mining above multiple aquifers," Mine Water and the Environment, vol. 38, no. 4, pp. 827-836, 2019.

[28] Q. Li and W. H. Sui, "Risk evaluation of mine-water inrush based on principal component logistic regression analysis and an improved analytic hierarchy process," Hydrogeology Journal, vol. 29, no. 3, pp. 1299-1311, 2021.

[29] W. Qiang, L. Yuanzhang, and Y. Liu, "Using the vulnerable index method to assess the likelihood of a water inrush through the floor of a multi-seam coal mine in China," Mine Water and the Environment, vol. 30, no. 1, pp. 54-60, 2011.

[30] W. P. Li, Y. Liu, W. Qiao, C. Zhao, D. Yang, and Q. Guo, “An improved vulnerability assessment model for floor water bursting from a confined aquifer based on the water inrush coefficient method," Mine Water and the Environment, vol. 37, no. 1, pp. 196-204, 2018.

[31] Y. Zhang and L. Yang, "A novel dynamic predictive method of water inrush from coal floor based on gated recurrent unit model," Natural Hazards, vol. 105, no. 2, pp. 2027-2043, 2021.

[32] X. Y. Shi, H. Q. Zhou, X. K. Sun, Z. Cao, and Q. Zhao, "Floor damage mechanism with cemented paste backfill mining method," Arabian Journal of Geosciences, vol. 14, no. 2, pp. 1-9, 2021.

[33] S. C. Yu, J. M. Xu, W. Zhu, S. Wang, and W. Liu, "Development of a combined mining technique to protect the underground workspace above confined aquifer from water inrush disaster," Bulletin of Engineering Geology and the Environment, vol. 79, no. 7, pp. 3649-3666, 2020.

[34] J. Hao, Y. K. Shi, J. H. Lin, X. Wang, and H. Xia, "The effects of backfill mining on strata movement rule and water inrush: a case study," Processes, vol. 7, no. 2, article 7020066, 2019.

[35] W. Zhu, S. Yu, D. Xuan, Z. Shan, and J. Xu, "Experimental study on excavating strip coal pillars using caving zone backfill technology," Arabian Journal of Geosciences, vol. 11, no. 18, p. 554,2018

[36] P. Hou, S. J. Su, X. Liang et al., "Effect of liquid nitrogen freezethaw cycle on fracture toughness and energy release rate of saturated sandstone," Engineering Fracture Mechanics, vol. 258, article 108066, 2021.

[37] J. Liu, Y. Xue, W. Chen, P. Hou, S. Wang, and X. Liang, "Variational phase-field model based on lower-dimensional interfacial element in FEM framework for investigating fracture behavior in layered rocks," Engineering Fracture Mechanics, vol. 255, article 107962, 2021.

[38] J. Liu, Y. Xue, Q. Zhang, H. Wang, and S. Wang, "Coupled thermo-hydro-mechanical modelling for geothermal doublet system with 3D fractal fracture," Applied Thermal Engineering, vol. 200, article 117716, 2022.

[39] X. Liang, P. Hou, X. J. Yang et al., “On estimating plastic zones and propagation angles for mixed mode I/II cracks considering fractal effect," Fractals-Complex Geometry Patterns and Scaling in Nature and Society, 2021.

[40] J. I. Israelsson, "Short description of FLAC version 3.2," Developments in Geotechnical Engineering, vol. 79, pp. 513-522, 1996. 